\title{
A Pragmatic Textual Analysis of English Sales Letters
}

\author{
WANG Hong-li \\ Xi'an Jiaotong University, Xi'an, China
}

\begin{abstract}
A sales letter appears typically at the initial stage of a business transaction, whose communicative purpose is to persuade readers to respond favorably to the product or service offered in the letter. This paper applies a pragmatic-oriented textual analysis to a 15 authentic English sales letter corpus with an aim at reporting its schematic structures at the macro level and the realization of politeness strategies at the micro level. The findings from the textual analysis can be used by language teachers to foster in students the development of a metacognitive awareness of the sales promotional genre. Also they can be introduced in the business writing course to increase the effectiveness of the instruction.
\end{abstract}

Keywords: sales letter, textual analysis, schematic structure, politeness strategies

\section{Introduction}

Every year, millions of dollar's worth of goods and services are sold through sales letters to customers, businesses, and industrials. A sales letter is in fact part of a business communication sequence, appearing typically at the initial stage of a business communication sequence, in what Pilegaard (1997, p. 225) called "making contacts" situations. Its social role is to find a buyer for a commodity or service offered in the letter. Of course, the buyer is just a potential buyer and the seller has to praise the commodity or service to what the buyer's appetite and persuade him/her to respond favorably to the letter. Thus, the most fundamental function of a sales letter is persuasive, in the sense that its writer aims to elicit a specific response from its readers. Besides, another accompanying function is informative, because persuasion is a complex communicative process, in order to facilitate the process, it is extremely necessary to provide readers with sufficient information.

According to Swales (1990):

A genre comprised a class of communicative events, the members of which share some set of communicative purposes. These purposes are recognized by the expert members of the parent discourse community, and thereby constitute the rationale for the genre. This rationale shapes the schematic structure of the discourse and influences and constrains choice of content and style. (p. 13)

As the sales letter is a purposeful communication event, without doubt it is also a specific genre. Then our research question becomes: How is the communicative purpose realized in this genre?

This paper tries to answer this question by adopting a special research perspective, which is pragmatic-orientated in nature in that the analysis applies not only the notion of move to the macro textual disposition but also the theory of politeness to the micro linguistic preferences. The analysis will surely show how

WANG Hong-li, associate professor at School of Foreign Studies, Xi'an Jiaotong University. 
the macro as well as micro textual choices interact in contributing to the achievement of the communicative purpose of the sales promotional genre. Before we carry on the study, let us review the notions we resort to a little bit.

\section{Theoretical Background}

Text patterning, i.e., the pragmatic disposition at the macro level, can be analyzed by using the notion of move, one of the identifying features of genres and thus a notion widely used in the analysis of discourse patterns (Bhatia, 1993, p. 35). A move is a meaningful unit represented in linguistic forms and related to the communicative purposes of the activity in which members of the community are engaged. Analyzing the move structure of a text would thus mean to assign a pragmatic function to a stretch of language and to build the schematic structure through which its communicative purpose is achieved.

Actions performed via utterances are generally called speech acts (Yule, 1996, p. 47). Speech acts can be classified as declarations, representatives, expressives, directives, and commissives in terms of the general functions they performed. Directives are those kinds of speech acts that speakers use to get someone else to do something. They express what the speaker wants. They are commands, orders, requests, and suggestions (Yule, 1996, p. 54). Sales letters are of course kinds of requests.

On the basis of structure, speech acts can also be distinguished as direct or indirect. In Universals in Language Usage (1987), Brown and Levinson, dealing primarily with requests, argue that politeness is a function of indirectness: The more indirect the request, the more polite it is, all other things being equal. Moreover, they define politeness as the means employed to show awareness of another person's face. Face has two dimensions: one positive and one negative. Positive face reflects the need to be accepted and to belong. Using positive politeness strategies, also called solidarity politeness by R. Scollon and S. Scollon (1981), the speaker seeks to reinforce the addressee's positive face by showing the addressee that two of them are cooperators with common goals and expectations. Negative face reflects the desire for independence, to be able to act freely and unimpeded by others. Respect is indicated with negative politeness strategies by showing that the speaker does not intend to limit the addressee's freedom of action.

There are three variables that influence the degree to which an act might threaten one's positive or negative face: (1) the social distance between the speaker and the addressee; (2) their "power" relative to each other; and (3) "the absolute ranking of imposition in the particular culture" (Brown \& Levinson, 1987, p. 76). As we know, sales letters are nicknamed as "junk mail" by consumers as they are usually unsolicited, thus unexpected or even unwelcome by the receiver. Only in rarest cases they are solicited or invited as the direct answers to the potential buyer's inquiries about products or services. Taking into such situation, we could conclude that the distance between the sales letter participants is usually great and much effort have to be put into reducing it. The distribution of power is asymmetrical in the sense that the addressee decides whether he/she wants to comply with the letter he/she receives and so is in a more powerful position than the sender. Besides, even if no request is ever directly made in the sales letter, we still could say that the request is implicit and thus a certain degree of imposition will be always present. Thus the politeness strategies are expected in the successful composition of this genre. In fact, the use of adequate politeness strategies may solve the sender's dual problem in his/her particular culture: to persuade the addressee that the offer is sensible and advantageous and make him/her respond favorably to the letter. 
Researchers have discussed numerous devices for creating politeness and given them different labels. For the present study purpose, we slightly modify the Pilegaard's (1997, p. 228) table of politeness strategies as follows (see Table 1).

Table 1

Politeness Strategies

\begin{tabular}{|c|c|c|c|c|}
\hline \multicolumn{3}{|c|}{ Positive politeness strategies } \\
\hline Claim common ground & $\begin{array}{c}\text { Focus on } \\
\text { cooperation }\end{array}$ & $\begin{array}{c}\text { Fulfill the receiver's } \\
\text { wants }\end{array}$ & $\begin{array}{c}\text { Express } \\
\text { appreciation }\end{array}$ \\
\hline Notice, attend to receiver & Use in-group identity markers & Negative politeness strategies \\
\hline \multicolumn{3}{|c|}{ Minimize imposition } & Dissociate receiver from act \\
\hline
\end{tabular}

The present corpus we are using composes 15 authentic sales letters written by native speakers of English. As we have mentioned above the solicited types are far more prevailing in our daily life, the ratio of solicited to unsolicited in the corpus is 13 to 2 .

\section{Analysis in Action}

\section{The Macro and Micro Textual Strategies}

Bhatia (1993, p. 46) used seven-move structure to label the sales letters. However, after careful analysis of the corpus, the author would like revise it slightly into the nine-move schematic structure, that is:

Move 1: Opening salutations;

Move 2: Headlines;

Move 3: Establishing credentials;

Move 4: Introducing the offer;

Move 5: Offering incentives;

Move 6: Using pressure tactics;

Move 7: Soliciting response;

Move 8: Ending politely;

Move 9: Closing salutations.

Next, we will examine the nine moves in details by analyzing examples from the sample letters.

Move 1: Opening salutations. Salutation is one of the indispensable components of a letter. Thus all the sales letters in the corpus have such a move. As we know, in English the level of acquaintance can be inferred from this initial greeting: The $\mathrm{T}$ (familiar) mode of address is characterized by an opening salutation such as "Dear (first name) or just "(first name)", while the V (formal) version identifies the reader by "Dear Mr. /Mrs. /(Surname)" or "Dear (lexical item such as friend, colleague, Business owner...)" or more deferential expressions like "Dear Sir/Madam" or "Dear Sirs". The familiar T level is never used in our corpus because of the business-like nature of the genre in question. Moreover in our corpus, we find six cases use positive politeness strategies of claiming common ground in opening salutations, that is, the in-group identity markers like "Dear friend" or Dear colleague". By doing this, the closeness, intimacy, and rapport between the participants may be created right from the very beginning of the letter. 
Move 2: Headlines. The move "Opening salutation" is followed by a headline in most cases, exactly speaking, $80 \%$ in our corpus. The function of this second move is to attract and capture the addressor's attention and impel him/her to read on the rest of the letter by highlighting the most striking appeals of the products for sale (see Example 1).

Example (1) Now you can donate money to Hemophilia Healthwatch without spending a dime.

In our corpus, modal auxiliaries verbs like "can" and/or adjectives such as "special", "new", "free", and so on always appear in headlines to convey a benefit or a promise to the reader (see Example 2).

Example (2) A new special report from Textiles Intelligence.

Move 3: Establishing credentials. This move serves the function of preparing the ground for the products offered in the letter. It can appear either before or interweave with the move "Introducing the offer". There is prevalence of positive politeness forms found in this move. For example, noticing the receiver's desires and/or needs in Example 3, attending to the receiver's problems in Example 4, focusing on cooperation in Example 5, and expressing appreciation in Example 6. Such high occurrence of positive politeness strategies in our corpus proves that the writers seek closeness and solidarity from the very beginning of the communication.

Example (3) You may in business, and need a way to monitor your accounts receivable.

Example (4) ... Your customers from other area of the state and country will not be able to reach you with your previous area code.

Example (5) We've had the happy experience of receiving one or more orders from you every year for several years. But... I note that you haven't bought anything from us for the past two years. This sets me to wondering:...

Example (6) Thanks for your recent inquiry, and your interest in Apple Computer.

Move 4: Introducing the offer. This is the most crucial move in sales letter, for it highlights the central selling point of the product. In this move, highly subjective adjectives are surely used to evaluate the product and thus heighten the persuasive effects (see Example 7).

Example (7) This unique property offers outstanding vacation benefits, considerable tax advantages and substantial real estate value at the most dynamic ski and summer resort in the East...

Moreover, in our corpus we find indirect questions, high-level modality markers, conditional adverbial clauses, and other mitigating devices are often used to soften the sender's weight of imposition on the addressee and thus to redress the face-threatening act of request. Both positive and negative politeness may at work in this move but positive strategies do appear more often than negative ones. Followings are some examples from the present corpus (see Examples 8-12). Note that the sentences in brackets are the move "Establishing Credentials" and words underlined are used to realize face saving acts.

Positive politeness strategy of focusing on cooperation.

Example (8) (Have your life become dull and routine?...) Why not leave your daily routine behind for awhile to travel with XANADU?

Positive politeness strategy of fulfilling R's wants.

Example (9) (How often have you seen it? The rumpled junior executive trying to make a good impression at a 3 o'clock meeting. But no matter how good his presentation, he fails. Why? Because...) Now you can avoid this rumpled syndrome with our Executive Broadcloth Shirts. 
Positive politeness strategy of claiming common grounds.

Example (10) I am pleased to recommend this very romantic gift for someone you love.

Negative politeness strategy of giving freedom of action.

Example (11) If you need to change your address, the name of your second vice-president or other details, we can make the changes for you without a redesign.

Negative politeness strategy of minimizing imposition.

Example (12) What's more, there's NO OBLIGATION for you to keep the shirts.

Although above seem to be the separate cases to readdress the receiver's positive and negative faces. However, it must be pointed out that in our corpus most writers resort to both strategies in one single sales letter and YOU-orientation are often adopted to realize politeness, which we will discuss in later part of the paper.

Move 5: Offering incentives. This move has the function of ultimately persuading the reader to clinch the deal by offering extra attractive benefits over and above what is provided in the package deal (see Example 13).

Example (13) We are pleased to inform you that if your company sponsor 6 or more staff for the course, we will offer you a discount of US\$100 per person.

Investigation into all examples of this move enables us to conclude its predominant grammatical pattern is: the main clause carrying the promise of extra benefit + if-clause.

Move 6: Using pressure tactics. This move has a very specific purpose: to prompt the already inclined or half-inclined customer to take a quick decision about the product being promoted. It is usually realized through cautioning the reader about the limited supply of the product (see Example 14) or the deadline for special offers (see Example 15).

Example (14) As the number of participants at each training program is limited, we would urge you to finalize as soon as possible your plan to participate.

Example (15) And last, because we expect to be deluged with work once the March deadline comes closer, until December 31 we can offer you a 10 discount off our already competitive prices.

Causal adverbial clauses introduced by "as" and "because" are often used when the write is trying to give a valid reason to justify the need for a prompt decision and substantially mitigate the imposition and realize the politeness of the offer.

Move 7: Soliciting response. All letters in the corpus have a final "Soliciting Response". This move calls for action such as farther inquires or immediate purchase and so on. This is the move where negative politeness strategies are mostly to be found, and the reason behind such a choice is clear: This is the part where the final request is made and the author has to mitigate the force of it if he/she wants to minimize the imposition and save his/her addressee's face. This is generally done by giving the buyer the freedom of action by not assuming that he/she will act. Thus freedom of action is given in a receiver-oriented fashion, i.e., basing it on the reader's willingness (see Example 16).

Example (16) ... We are hoping you'll spend a minute to fill out the enclosed application and mail it in...

Here, the author mitigates the illocutionary force by reporting on his/her desires rather than making an explicit request and by giving himself/herself a very passive role. He/she introduces the request using the modal adjunct "we are hoping" leaving the reader the option to comply. Sentences like this which begin with a modal adjunct ("I hope") followed by a will-sentence whose subject is the receiver is a very effective pattern to make 
the receiver feel that he/she is not coerced. Besides this pattern, conditionals can equally be employed to realize the same politeness strategy (see Example 17).

Example (17) We would be very grateful if you would complete the enclosed questionnaire and return it to our office.

Here, it is clear that by using the hedge underlined above, the author avoids presumptions about the receiver and emphasize that the establishment of a satisfactory business contact is up to the receiver's willingness to act. In Example 17, subjunctive mood combined with if-structure minimizes the imposition of the request the sender is making by stretching the time of action into the future.

Moreover, in our corpus we still find that positive politeness strategies that focus on cooperation abound and are more frequent in this move than other two positive forms (see Example 18).

Example (18) Just stop in our shop at 381 Main St. from 8:30 to 5:30 Monday through Saturday, or call me at 752-8000 today.

Last, even the direct form known as being on record is sometimes used to require the addressee's action (see Example 19).

Example (19) Call us toll free at 800-555-8000 or fill in the enclosed card today.

Such appearance of the direct speech is not surprising and also not very rear in our corpus because, besides courtesy, clarity and conciseness are also principles of business communication.

The following is the statistics about the occurrence of different forms of soliciting response (see Table 2).

Table 2

The Distribution of Three Different Forms of Soliciting Response

\begin{tabular}{lccc}
\hline Form & Negative positive strategy & Positive politeness strategy & Bald on record \\
\hline No. of occurrence & 9 & 6 & 2 \\
Frequency $(\%)$ & 52.9 & 35.3 & 11.8 \\
\hline
\end{tabular}

Move 8: Ending politely. The underlying rationale behind this move is the universally-accepted fact that business can flourish only by maintaining friendly, courteous, and pleasant relations. Thus, this closing move is used to express the writer's hope and expectation that a relationship may be built with the potential or old customer in the near future. This final move mainly realizes the positive politeness strategies that focus on cooperation (see Examples 20-21).

Example (20) Welcome to the world of Apple!

Example (21) Thank you for your support.

Furthermore, all the letters in the corpus have a closing salutation, which all takes the form as "sincerely", "sincerely yours", "yours faithfully", and so on.

\section{Reference and YOU-Orientation}

References to the sender and the receiver are always pronominal or lexical. In our corpus, the reference to the sender is mostly realized through the vague use of the first person plural pronoun "we, us and our". Such vague use applies to "specific individuals but they are not identified by the speaker" (Kitagawa \& Lehrer, 1990, p. 742). And the reference to the writer takes the form of lexical items (friend, business owner, client, Sirs/Madam) at the opening salutation and the second person pronoun (you and your) in the rest part of the letter. 
It is well-known that a reader-oriented perspective (YOU-orientation) is generally preferred in business correspondence. In sales letters, the power position of the customer makes the text centered around him/her, i.e., how the product or service being offered can make his/her life better. Readers are persuaded into buying on the grounds of what the product or service does for them. As a consequence, the writer may undergo a process of shadowing. Look at the body of one sample letter chosen from the corpus.

We've come to you again for help, but this time we're asking you to put something new into your wallet, not take something out.

Through a special arrangement with the Second National Bank of Boonton, we've created a special visa card that earns money for hemophilia research when you apply for it, and every time you use it.

That's right - just by applying for the card, you earn $\$ 1$ for our cause. Once the card is issued to you, Hemophilia Healthwatch receives 1 percent of every purchase you make using the card. So when you're buying clothing and other essentials for your family, or enjoying a night or month out on the town - and charge the expenses to the $\mathrm{HH}$ Visa card-you're also hastening the day when hemophiliacs no longer need to live in fear.

If you like this idea but think you're already all set on the credit card front, think again. Throughout your first year of enrollment, the $\mathrm{HH}$ visa card carries the low, low interest rate of only 8 percent. And you can transfer your outstanding balances of any amount on any existing Visa or MasterCard account to your new HH Visa card with just a telephone call.

We appreciate your generous assistance in the past, and we're hoping you'll spend a minute to fill out the enclosed application and mail it in, so that a portion of the money you spend in the ordinary course of life goes toward easing the burden on hemophiliacs and their families.

In this sample, there are total 20 uses of second-person pronoun in contrast to only five appearances of first-person plural pronoun. Clearly throughout the body of this sample letter, references to the writer are only located in "Offering products" and "Soliciting response". In the rest most part, the writer disappears to leave room for the benefits that the product can have on the addressee, which is the real subject of sales letters.

YOU-orientation is not necessarily realized by the disappearance of the reference to the author himself/herself. It can also be indicated by two of the Leech's politeness principles. According to Leech (1975), to insure the successful and smooth flow of communication one should comply with Tact Maxim, i.e., maximize benefit to others and minimize cost to others, and Generosity Maxim, i.e., minimize benefit to self and maximize cost to self. The following examples are from a sample letter, in which the shadowing of the writer is missing, two Leech's sub-principles of politeness at work instead (see Examples 22-23).

Example (22) At no cost or obligation, we'll be happy to look at your existing materials to see if creative solutions such as stick-on corrections would enable you to use up your materials on hand before reprinting them.- - Tact Maxim

Example (23) At our expense we will keep a copy of your materials on hand in digital form for at lest three years, so that if you need to change your address, the name of your second vice-president or other details, we can make the changes for you without a redesign.-Generosity Maxim

\section{Conclusions}

The pragmatic textual analysis into the present sales letter corpus indicates that the sales letter, as a special promotional genre, enjoys a rather formulaic organizational uniformity at both the macro level (moves making up a genre) and the micro level (speech acts realizing the moves).

The formulaic schematic structure of the sales letter is: Opening salutations $\rightarrow$ Headlines $\rightarrow$ Establishing 
credential $\rightarrow$ Introducing the offer $\rightarrow$ (Offering incentives $\rightarrow$ Using pressure tactics) $\rightarrow$ Soliciting response $\rightarrow$ (Ending politely) $\rightarrow$ Closing salutations. Here, the direction of the arrowhead indicates the preferred sequences of the moves and the moves in brackets are the peripheral moves. The emergence of obligatory center moves is decided by the conventional letter formats and the persuasive and informative communication purpose of sales promotional genre.

Both positive and negative politeness strategies appear in the sales letter. However, positive politeness strategies are more preferred by native writers for they are more recurrent that negative ones and this is especially true at the beginning of the letter. Most negative politeness is concentrated near the end of the letter, that is, in the "Soliciting response" move. Such distribution of positive and negative politeness strategies in the present corpus confirms Pilegaard's (1997, p. 235) conclusions, according to which "Both sellers and buyers 'making contacts', reserve the negative politeness strategies for the propositional section and the positive strategies for the non-propositional sections". This micro discourse preference could be explained by noting that Anglo-Americans look for solidarity, closeness, and cooperation between interactants immediately at the beginning of the business relationship.

Modality, mood, conditional clauses, in-group markers, questions of the why + interrogative negative, and other mitigating devices are used to realize politeness strategies. A retrospect into the examples presented in the paper indicates that modality play an especially important role in the expression of politeness in our corpus.

As we know, a reader-oriented perspective (YOU-orientation) is generally preferred in business correspondence to convey politeness of the writer. In sales letters, such a perspective is not only realized by the shadowing process of the writer but also by observing Leech's politeness principle of tact maxim and generosity maxim.

Above are the brief summary of the research findings. We have to point out that conventionalized schematic structure of each genre is creativity in nature, that is, both the generic composition at macro textual level and micro linguistic level allow variations to achieve special effects or private intention. However, such variations are limited within the boundaries of a particular genre. Anyway, we strongly believe that these findings can be used by ESP (English for Special Purposes) teachers to foster in students the development of a metacognitive awareness of the sales promotional genre. They can be introduced in the business writing course to increase the effectiveness of the instruction. The possible pedagogical approach may become the further research focus.

\section{References}

Bhatia,V. K. (1993). Analysing genre: Language use in professional settings. London: Longman.

Brown, P., \& Levinson, S. (1987). Politeness: Some universals in language usage. Cambridge: Cambridge University Press.

HE, Z. X. (2000). A new introduction to pragmatics. Shanghai: Shanghai Foreign Language Education Press.

Kitagawa, C., \& Lehrer, A. (1990). Impersonal uses of personal pronouns. Journal of Pragmatics, 14, 739-759.

Leech, G. (1975). A communicative grammar of English. London: Longman.

Paltridge, B. (1995). Working with genre: A pragmatic perspective. Journal of Pragmatics, 24, 393-406.

Pilegaard, M. (1997). Politeness in written business discourse: A textlinguistic perspective. Journal of Pragmatics, 28, $223-244$.

Scollon, R., \& Scollon, S. (1981). Narrative, literacy and face in interethnic communication. Norwood, N.J.: Ablex.

Swales, J. (1990). Genre analysis: English in research and academic settings. Cambridge: Cambridge University Press.

Yule, G. (1996). Pragmatice. Oxford: Oxford Univesity Press. 